\title{
Cotinine Effects on Peripheral Nerve Injuries: An Experimental Study
}

\author{
Periferik Sinir Yaralanmalarında Kotinin Etkileri: Deneysel Bir Çalışma
}

\author{
Rifat AKDA $\breve{G}^{\mathbf{1}}$ \\ (D) 0000-0001-7638-8361 \\ Ali DALGIÇ \\ (D) 0000-0002-5575-4825 \\ Gülnur TAKE ${ }^{3}$ \\ (D) 0000-0002-3661-3488 \\ Uğur SOYLU ${ }^{1}$ \\ (10) 0000-0003-0336-3926 \\ Emin ÇAĞIL \\ (D) 0000-0003-1376-4053
}

\begin{abstract}
Aim: Cigarette smoking is a common addictive manner and one of the greatest threats to health. Nicotine is one of the main components of cigarette. The aim of this study was to reveal the effect of cotinine which is an active metabolite of nicotine, on peripheral nerve injury in rats.

Material and Methods: We studied 42 male adult albino-Wistar rats that were divided into three groups with simple randomization method. Group 1 were given Cotinine ${ }^{\circledR}$ (C-5923sigma) intraperitoneally, at a dose of $0.3 \mathrm{mg} / \mathrm{kg} / \mathrm{day}$ for 21 days. Group 2 were given ethyl alcohol, the solvent of Cotinine in the same way, dose and period. Group 3 were subjected to sciatic nerve compression injury by a clip, which has a closing pressure of $50 \mathrm{gr} / \mathrm{cm}^{2}$. Group 1 and 2 were subjected to the same type of injury at the end of 21 days. Four weeks later after trauma, both three groups were sacrificed and injured sciatic nerve sections are taken for histopathological analysis.

Results: It was observed that cotinine aggravated the traumatic degeneration and as privileged caused to fibrosis. In the Schwann cells of thick-myelinated fibers exhibited higher grades of degeneration and mitochondrial augmentation. According to the multiple comparison results, the number of Wallerian degenerations in the trauma group was significantly lower than in both the drug-control $(\mathrm{p}=0.016)$ and drug $(\mathrm{p}<0.001)$ groups. This situation was estimated as a response to oxidative stress.

Conclusion: This study reveals that peripheral nerve regeneration after traumatic injury may be affected negatively in smokers.

Keywords: Cigarette; nicotine; cotinine; peripheral nerve; trauma.
\end{abstract}

ÖZ

Amaç: Sigara içmek yaygın bir bağımlılık biçimidir ve sağlık için en büyük tehditlerden biridir. Nikotin, sigaranın ana bileşenlerinden biridir. Bu çalışmanın amacı, nikotinin aktif bir metaboliti olan kotininin sıçanlarda periferik sinir hasarına etkisini ortaya koymaktır.

Gereç ve Yöntemler: Basit randomizasyon metoduyla üç gruba ayrılan 42 erkek yetişkin albino-Wistar sıçan üzerinde çalıştık. Grup 1'e 21 gün boyunca $0,3 \mathrm{mg} / \mathrm{kg} / \mathrm{gün}$ dozunda intraperitoneal olarak Cotinine ${ }^{\circledR}$ (C-5923-sigma) verildi. Grup 2'ye aynı şekilde Cotinine çözücüsü olan etil alkol, aynı doz ve sürede verildi. Grup 3, kapanma basıncı $50 \mathrm{gr} / \mathrm{cm}^{2}$ olan klips ile siyatik sinir kompresyonu yaralanmasına maruz bırakıldı. Grup 1 ve 2 ise 21 gün sonunda aynı tipte yaralanmaya maruz bırakıldı. Travmadan dört hafta sonra bütün gruplar sakrifiye edildi ve hasarlı siyatik sinir kesitleri histopatolojik analiz için alındı.

Bulgular: Kotininin travmatik dejenerasyonu şiddetlendirdiği gözlenmiştir ve ayrıca kotininin özellikle fibrozun artışına neden olduğu görülmüştür. Kalın miyelinli fiberlerdeki Schwann hücrelerinde daha yüksek derecelerde dejenerasyona sebep olduğu ve ek olarak, bu hücrelerde mitokondriyal artış olduğu görüldü. Çoklu karşılaştırma sonuçlarına göre travma grubunda Wallerian dejenerasyon sayısı hem ilaç kontrol $(\mathrm{p}=0,016)$ grubu hem de ilaç grubuna $(\mathrm{p}<0,001)$ göre anlamlı derecede daha düşüktü. Bu durumun oksidatif strese bir yanıt olarak geliştiği tahmin edilmektedir.

Received / Geliş Tarihi : 12.03.2021 Accepted / Kabul Tarihi : 27.06.2021 Available Online / Sonuç: $\mathrm{Bu}$ çalışma, sigara içenlerde travmatik yaralanma sonrası periferik sinir yenilenmesinin olumsuz şekilde etkilenebileceğini ortaya koymaktadır.

Çevrimiçi Yayın Tarihi : 13.07.2021 Anahtar kelimeler: Sigara; nikotin; kotinin; periferik sinir; travma. 


\section{INTRODUCTION}

Precise estimation of smoking status is important for detection of smoking-attributable diseases and the effect of smoking on diseases. Also, it is crucial to authenticating the dimensions of the tobacco use, anticipating population risk, smoking-related disease burden, and interpreting the improvement of smoking cessation programs all along the world (1,2). The most commonly used tool is a standardized questionnaire. It is used to determine smoking prevalence and exposure to passive smoke. However, a standardized questionnaire might not always indicate a subject's real smoking status because of limitations. These limitations are a problem in recall the details of past smoking and having a desire to hide smoking because of social embarrassment. The questionnaire bias may increase over time. While social norms are altering, smoking has become less admissible. Moreover, a questionnaire may not be completely evaluate the passive smoke exposure of nonsmokers. The nonsmoker people who are exposed to smoke do not realize how much they are exposed to smoke. In this case, it is not possible to determine the level of exposure by a questionnaire. Also, this situation is valid for determination of smoking status of recent former smokers (3). For all these reasons, biological markers of cigarette smoking and passive exposure have been used to determinate smoking status, to monitor and track population exposure to cigarette smoke with respect to people, place, and time (4). Particularly, it has been preferred in prevalence surveys and epidemiologic studies for many years $(5,6)$. Although the concentrations of tobacco-related components and their metabolites are used as biomarker mainly, the interaction between smokerelated chemical products and target molecules in biological materials also can be used (7). One of the most important biomarkers is nicotine and its metabolites $(8,9)$. In humans, more than $80 \%$ of nicotine is metabolized to cotinine (10,11). Generally, nicotine is absorbed as particle-bounded or vapor phase by the body. First, nicotine is mostly metabolized by cytochrome P450 2A5 (CYP2A5) and cytochrome P450 2A6 (CYP2A6) enzymes to cotinine $(10,12)$. Nicotine's half-time in the body is approximately 2-3 hours (13). Second, cotinine is mostly metabolized to its major metabolites, trans-3'hydroxycotinine and its glucuronide by the liver $(10,14)$. Only $10-15 \%$ of the total cotinine is excreted in the urine. Half-time of cotinine in the body is approximately 12-20 hours (15). This physiologically active form of cotinine tends to accumulate in the body as a result of smoking and exposure to tobacco smoke. The metabolic rate of cotinine synthesis is determined by a person's genetic background. Therefore, the rate of cotinine synthesis and accumulation in the body varies according to ethnicity (16). The studies show that body clearance of cotinine has a higher average for Caucasians than African Americans $(15,16)$. Food consumption is also important for nicotine metabolization besides genetic factors (16). For example, grapefruit juice has been shown to prevent the production of cotinine by inhibiting the activity of CYP2A6 (17). De Leon et al. (18) showed that cotinine, the major metabolite of nicotine, is an appropriate determinant in revealing the effects of tobacco products due to its long half-life and metabolic changes.
Tissue damage by applying local compression or incision on the peripheral nerve results in increased regenerative capacity in the peripheral nervous system, which continues with the Wallerian degeneration process, in contrast to insufficient axonal regeneration in the central nervous system (Table 1). These findings have been demonstrated by the experiments conducted by Cajal (19). Similarly, this process can be detected by electron microscopic analysis. Parameters evaluated in neural tissue after trauma in electron microscope; intracytoplasmic edema, nucleus changes, mitochondrion formation, axonal changes and myelin sheath changes (19).

According to these findings, smoking habit has a negative effect on oxidative stress in addition to many harms it causes in the body. Evaluation of local oxidative stress after peripheral nerve injury is necessary to understand and improve the healing process of the nerve. In this study, we aimed to show the effect of smoking habit on peripheral nerve damage via cotinine, a metabolite of nicotine.

\section{MATERIAL AND METHODS}

Animal experiment protocol and guidelines of study was ratified by Ethical Committee of Ankara Training and Research Hospital (Decision no: 0291/2155). Animal Laboratory of the same hospital was used for all experimental procedure. 42 male adult albino-Wistar rats with body weight 180-220 gr were used. All rats had been 4-6 months old. Standardized conditions were prepared for rats. They were put in a standard laboratory cage, sufficient food and water, at $18-21^{\circ} \mathrm{C}$. The light and dark cycle was divided equally 12 hours of light and dark (20).

\section{Anesthesia and Surgical Procedure}

The rats were divided into 3 groups as drug, drug-control and trauma with simple randomization method. It was arranged as 14 rats in each group. Cotinine ${ }^{\circledR}$ (C5923Sigma) was administered intraperitoneally to the first group at a dose of $0.3 \mathrm{mg} / \mathrm{kg} / \mathrm{day}$ for 21 days. Ethyl alcohol, which is the solvent of Cotinine $\AA$, was applied to the second group. Ethyl alcohol was administered intraperitoneally for 21 days in a volume equal to the amount of Cotinine given to the first group. The third group is the trauma group and only compression damage was done with the clip that was closed with a pressure of $50 \mathrm{gr} / \mathrm{cm}^{2}$. Similarly, compression injury was applied to the first and second groups at the end of 21 days.

Four weeks later after trauma, both three groups were sacrificed and injured sciatic nerve sections are taken for histopathological examination. Subjects were fasted 12 hours before the surgical procedure. All subjects were weighed before the procedure. Surgical procedures were performed under general anesthesia. For this purpose, Ketamine Hydrochloride (Ketalar ${ }^{\circledR}, 5 \%$ solution, with Parke Davis License and Eczacıbaşı İlaç Sanayi) $50 \mathrm{mg} / \mathrm{kg}$ and Xylocaine (Rhompun ${ }^{\circledR}, 2 \%$ solution Bayer) $10 \mathrm{mg} / \mathrm{kg}$ were added. The mixture was given intraperitoneally $(20,21)$. Under general anesthesia, the skin was shaved in the prone position, including the sacrum and both lower extremities, and superficial sterilization was achieved with polyvinylpyrolidone iodine (Batticon ${ }^{\circledR}, 10 \%$ solution, Genesis İlaç Sanayi). A longitudinal skin incision was made at the trochanter level in the proximal right lower extremity, and the skin and subcutaneous tissue were 
passed through. The gluteus maximus muscle was incised vertically at the trochanter level with its fascia and dissected, and the sciatic nerve just below it was explored. The sciatic nerve was carefully dissected from the surrounding tissues, preserving it with its epineurium. Nerve damage was created using a clip (Yaşargil FE 693 temporary aneurysm clip - Aesculap) with a compression force of $50 \mathrm{~g} / \mathrm{cm}^{2}$ (mean compression time 1 minute) in each rat sciatic nerve $(21,22)$. The incision was closed anatomically after the sciatic nerve injury was created. The incision was reopened by giving general anesthesia to the rats 4 weeks after the trauma. The damaged sciatic nerve segment was exposed and samples were taken including the proximal and distal parts for histopathological examination. At the end of the experiment, the rats were sacrificed with pentobarbital.

\section{Examination by Light and Electron Microscope}

Tissue samples were divided into $1 \mathrm{~mm}^{3}$ pieces and the tissue samples were fixed in $0.1 \mathrm{M}$ phosphate buffered $2.5 \%$ glutaraldehyde ( $\mathrm{pH} 7.4$ ) for 2 hours. At the end of the fixation period, the tissues were washed 3 times with a tampon for 1 hour. And after washing, post-fixation was performed by $1 \%$ tic osmium tetraoxide active. At the end of the period, the tissues passed through graded alcohol series for dehydration. Finally, tissues that were activated by propylene oxide were blocked with the embedding material prepared with Araldite CY212 kit. Semi-thin sections were taken from the blocks polymerized for 48 hours in a $56{ }^{\circ} \mathrm{C}$ oven and dyed with toluidine blue and examined under a light microscope. Thin sections taken from the marked areas were stained with uranyl acetatelead citrate, evaluated by Carl Zeiss EVO LS 10+ ED transmission electron microscope (TEM) and illustrated at appropriate magnifications reflecting the findings.

For assessment of histological scoring and changes of myelinated fibers, specimens were examined by light microscopy (Table 1). More than 12 microscopic fields were selected randomly from injured nerve specimens of each rat. Then, a protocol used for counting degenerated axons. The protocol consisted of starting from the first right corner of the rectangular field to the last left corner. All samples evaluation were performed by two independent histopathologists blind to the present study.

\section{Statistical Analysis}

Statistical analyses were performed by the SPSS v.26 statistical package. Normality assumption was examined using Shapiro-Wilk test. Kruskall-Wallis test was used to compare groups and Mann-Whitney $U$ test with Bonferroni adjustment was performed for post hoc comparisons. Descriptive statistics were presented as median (interquartile range) [min-max], and a $p$ value of 0.05 was considered statistically significant.

\section{RESULTS \\ Semi Thin Section Analysis Results}

In the sciatic nerve semi-thin sections that belong to the drug-control group, the epineurium and perineurium structures were observed to be normal. Schwann's cells and axonem were normal in myelinated and unmyelinated nerve fibers. While sporadic separations in the myelin sheath were determined in thick myelinated fibers, this finding was evaluated due to the physical compression that occurred during dissection. Thin fibers had normal texture (Figure 1).

In the semi-thin section evaluation of the trauma group, the epineurium and perineurium were observed with normal structure. Unlike the other groups, separation of myelin sheaths and myelin sheath duplication were noted. In addition to axon withdrawal and local thickening of myelin

Table 1. Histological grading score of nerve injury

\begin{tabular}{cl}
\hline Histology Score & Grade \\
\hline 0 & Normal \\
1 & Duplication of the myelin sheath \\
2 & Undulation of the myelin sheath \\
3 & Axonal degenerations (axonal withdrawal) \\
4 & Nerve fibers with severe degeneration \\
\hline
\end{tabular}
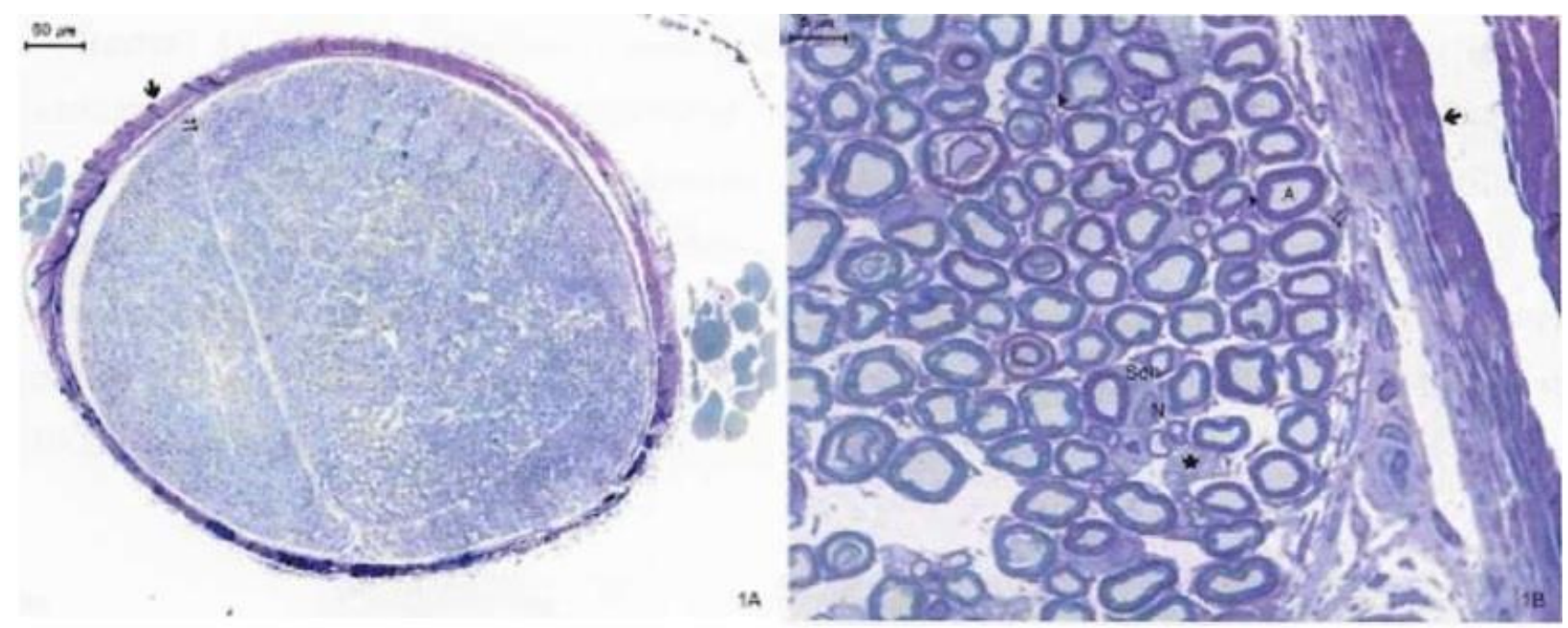

Figure 1. The epineurium $(\wedge)$ and perineurium $(\Rightarrow)$ structures were observed normally in the sciatic nerve semi-thin sections belonging to the drug-control group (1A, x100). Myelinated nerve fibers and unmyelinated fibers, Schwann cells and axonem were normal. Partial separations (>) due to physical compression of the myelin sheath were detected in some thick myelinated fibers (1B, x1000, Toluidine Blue). 
sheath, also Schwann cell hypertrophy were prominent in the trauma group. Another striking degenerative change was Schwann cells' pyknotic nucleus structure. It was noted that Schwann cells with pyknotic nuclei were commonly observed at unmyelinated fibers. This finding was accepted as an indicator of the cells' apoptosis process. Endoneural edema was another distinguishing feature in this group.

In the drug-control group which applied trauma + ethyl alcohol (solvent of cotinine), the findings were generally similar to the trauma group. In the drug-control group, mast cell infiltration was observed in the connective tissue of the nerve. These findings were interpreted as the subjects' response to alcohol.

In the drug group which cotinine was administered, intense degenerative changes were observed in the sciatic nerve. While detachment and duplication in the myelin sheath were clearly observed, the most typical finding of this group was myelin sheath hypertrophy. It was observed that the axonemic structure disappeared in some nerve fibers. It was noteworthy that the myelin sheath ondulations and the pyknotic nucleus appearance in Schwann cells became common in this group. Nerve loss was also observed in some areas due to intense degeneration in the myelin sheath. Fibrosis and edema in endoneurium was another distinguishing feature of this group. Mast cell infiltration was evident in the nerve sheaths in this group as well (Figure 2). Distribution of Wallerian degenerations measurement in all groups was illustrated at Table 2 . There was a statistically significant difference between the groups in terms of axon numbers with Wallerian degeneration $(p<0.001)$. According to the multiple comparison results, the number of Wallerian degenerations in the trauma group was significantly lower than in both the drug-control $(\mathrm{p}=0.016)$ and drug $(\mathrm{p}<0.001)$ groups. Also, the difference between the drug-control and drug group was also significant $(\mathrm{p}=0.005)$. Comparison of the number of axons with Wallerian degeneration between the trauma, drug-control and drug groups was shown in Figure $3 \mathrm{a}$ and $3 \mathrm{~b}$.

\section{Electron Microscopic Examination Results}

In the electron microscopic examination of the trauma group, although small myelinated nerve fibers were observed in normal structure, various degenerative changes were observed in large fibers. Local dilatations were observed in the myelin sheaths in a group of fibers. In a group of nerve fibers, it was observed that dilatations caused myelin duplication. Myelin ondulation was detected in large fibers in patches. It was remarkable that

Table 2. Wallerian degenerations measurement in all groups

\begin{tabular}{lc}
\hline Groups & $\begin{array}{c}\text { Number of Axons with Wallerian } \\
\text { Degenerations }\end{array}$ \\
\hline Trauma & $21(2.5)[18-23]$ \\
Drug-Control & $25(2.3)[22-29]$ \\
Drug $(0.3 \mathrm{mg} / \mathrm{kg} /$ day $)$ & $32(2.0)[30-35]$ \\
\hline
\end{tabular}

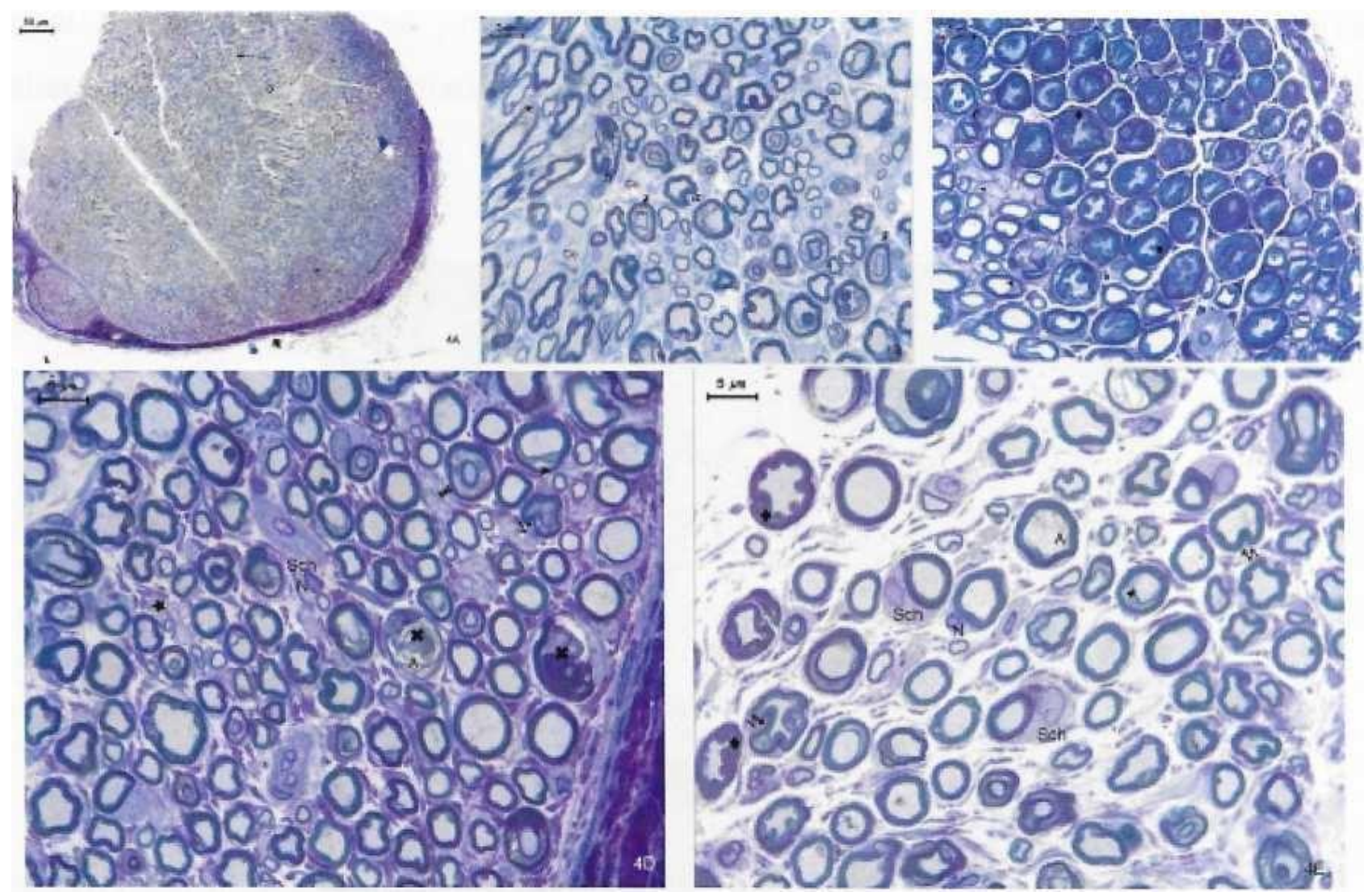

Figure 2. In the group in which cotinine was applied with trauma, epineurium ( $\bullet$ $)$ and perineurium (concealed, 2A x100) in the semi-thin section evaluation with small magnification of the sciatic nerve. It is observed that the axonem $(0)$ structure disappears in some fibers $(\mathbf{2 B}, \mathrm{x} 1000)$ with thickening $\left(^{*}\right)$ to form corrugations in places $(\mathbf{2 C}, \mathrm{x} 1000) .(\mathrm{A})(\mathbf{2 D}, \mathrm{x} 1000)$, hypertrophic Schwann cells (Sch), Schwann cells with locally picnotic nucleus (N) (2E, x1000, Toluidine Blue). 
the Schwann cells surrounding these fibers had an increase in mitochondria and their matrix was electron-dense. Nuclear degradation was observed in Schwann cells surrounding the unmyelinated fibers.

The general appearance of the sciatic nerve was observed to be normal in the electron microscopic examination of the drug-control group. It was determined that the findings were generally identical with the trauma group. Degenerative changes at different levels in the myelin sheath, mitochondrial density in Schwann cells of myelinated fibers where ondulation was observed. Also, hypertrophy in most Schwann cells were similar to the trauma group (Figure 4).

In the electron microscopic examination of the cotinine administered drug group, irregularities in the course of myelin were evident, especially in large fibers. The most prominent change in this group was axon recession, especially observed in myelinated nerve fibers. In addition, fibrosis caused by the increase in collagen fiber in the endoneurium was another distinctive finding (Figure 5).

As a result, it was observed that cotinine administration increased the degeneration caused by trauma. Also, it was shown that cotinine administration caused fibrosis exclusively. The myelinated fibers were the most affected fiber type in the sciatic nerve by trauma. The mitochondrial increase in Schwann cells observed with trauma was evaluated as the response of the cells to oxidative stress. Moreover, it was concluded that myelin sheath degeneration was the result of oxidative stress.
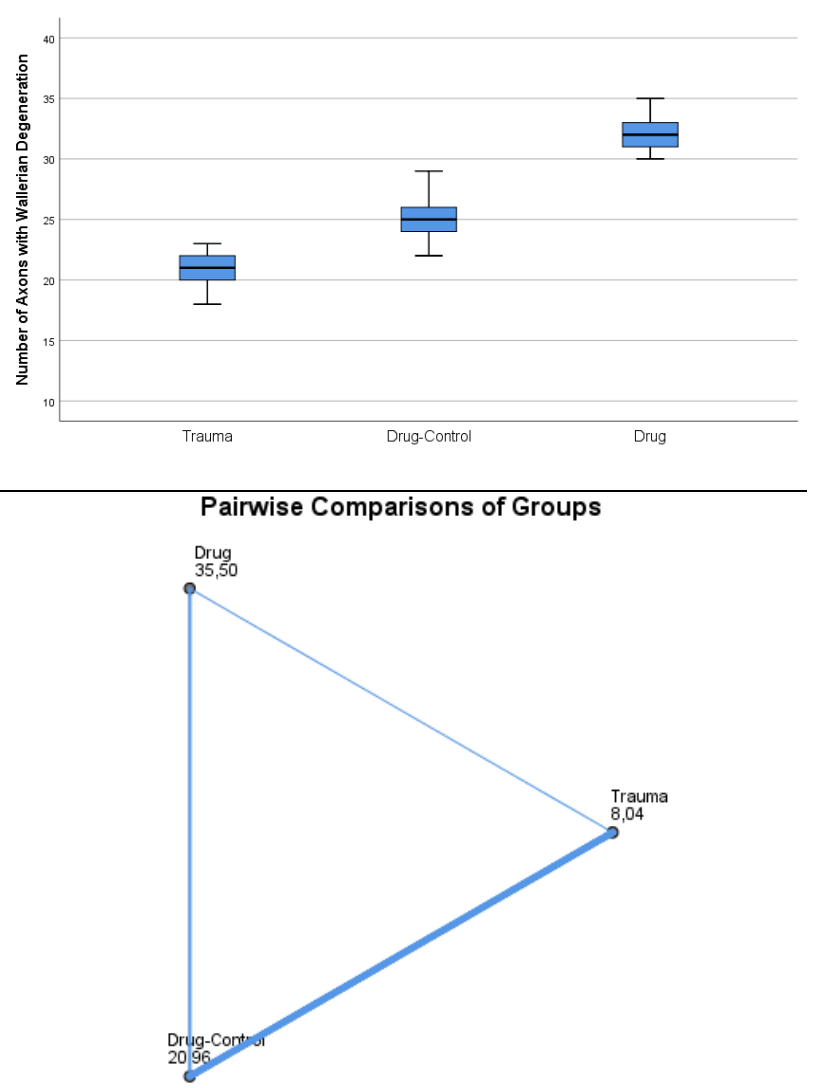

Each node shows the sample average rank of Groups.

Figure 3. Number of axons with Wallerian degeneration in groups (3A) and multiple comparison of groups (3B)

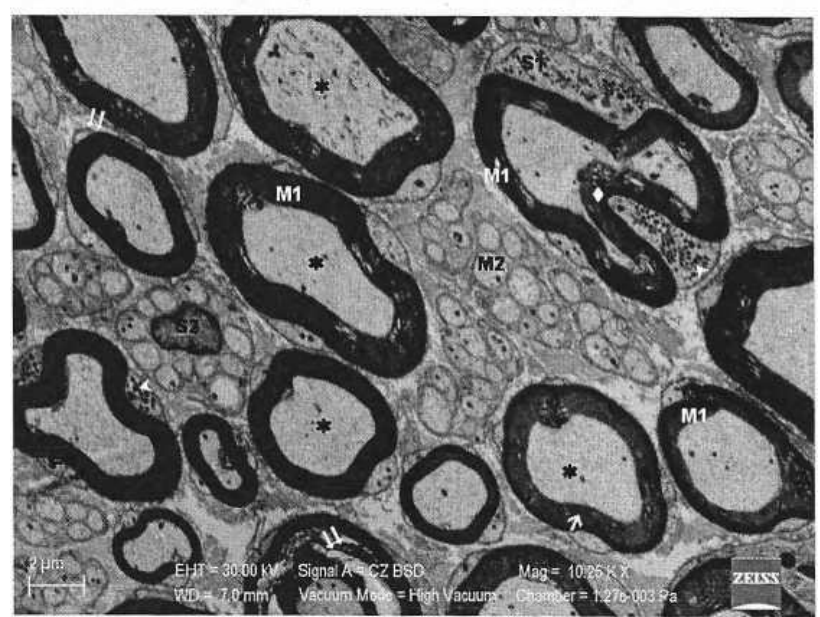

Figure 4. Drug-control group electron microscopic picture.

M1: myelinated nerve fiber, M2: Unmyelinated nerve fiber, S1: Hypertrophic Schwann cell, *: axonem, ith: Duplicate separations in the myelin sheath of myelinated nerve fibers, 'f: Decrease in electron density in the inner part of myelinated nerve fibers before separation, : Undulation in myelin sheath, >: Electron-dense matrix mitochondria, Top: endoneurium where edema is observed locally (Uranyl acetate - lead citrate).

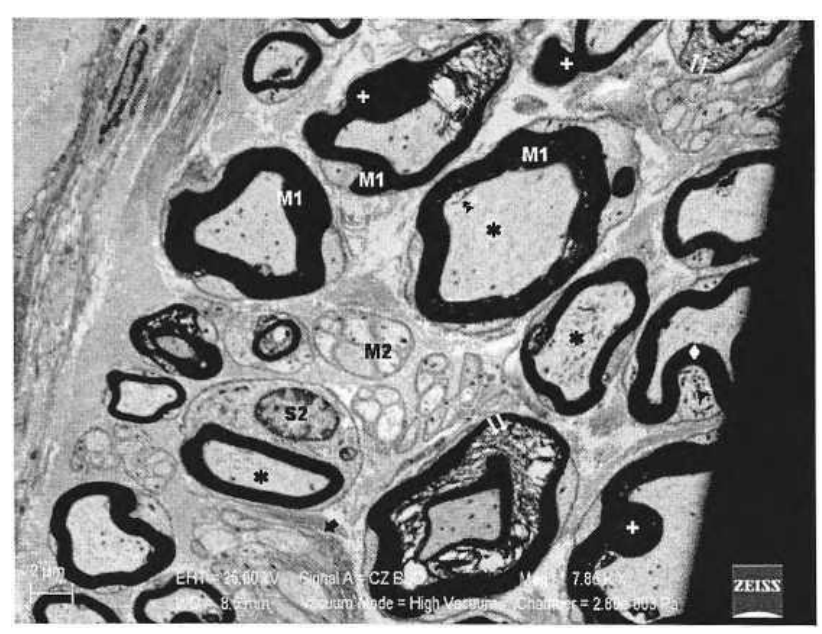

Figure 5. Electron microscopic picture of the Cotinine administered drug group. M1: myelinated nerve fiber, M2: Unmyelinated nerve fiber, S2: Schwann cell belonging to the unmyelinated nerve, *: axonem, ÎT: Separations in the myelin sheath of myelinated nerve fibers, +: Irregular course in myelin sheath, $\bullet$ : Ondulation in myelin sheath, >: Electron dense matrix mitochondria, $\longrightarrow$ : Axon withdrawal, $\bullet:$ Fibrosis in the endonorium (Uranyl acetate - lead citrate).

\section{DISCUSSION}

The effects of nicotine on oxidative stress and neural protection differ in terms of applied dose and mechanism. This two-way effect is thought to be due to the nicotine dose exposed and the mechanism of action. Nicotine at very high doses (1/10 microM) increases lipid peroxidation, while at very low doses $(10 \mathrm{pM})$ it acts as an antioxidant. It probably inhibits the Fenton reaction by binding excess iron in the environment at low doses. On the other hand, it may also reduce the formation of superoxide anions by binding NADH and disrupting the mitochondrial electrotransfer chain $(22,23)$. 
The effect of cotinine, the main metabolite of nicotine, on human metabolism has not been studied sufficiently. In humans, about $70-80 \%$ of nicotine is converted into cotinine. The half-life of cotinine is longer than nicotine and its residence time in the bloodstream is 48-96 hours. Since blood cotinine level is proportional to exposure to cigarette, cotinine levels are evaluated as an indicator of nicotine exposure $(10,23)$.

In studies conducted to investigate the adverse effects of smoking, it has been reported that pyridine and pyrazine content cause toxic effects by inhibiting angiogenesis $(24,25)$. Therefore, although there is information that smoking has a teratological effect by causing developmental malfunctions of various organs by inhibiting angiogenesis, no statistical information has been revealed $(26,27)$. However, it has been reported that it affects the vascular endothelial structure in adults and so causes coronary artery disease and cerebrovascular strokes (28). On the other hand, in studies on nicotine intake during pregnancy has been reported that causes damage to brain neuron cells during the neurulation phase of embryogenesis (29).

Peripheral nerve damage is begun with compression pressure and capillary pressure's encounter. When the compression pressure on peripheral nerves is exceeded capillary perfusion pressure limits, ischemia occurs. Ischemia and injury to peripheral nerves cause microvascular damage. This vascular damage and impairment of perfusion can cause to endoneural edema and promote the increase of endoneural fluid pressure. Moreover, oxidative stress-induced cell impairment follows the ischemia (20). After the ischemia, if reperfusion is achieved, blood flow provide oxygen, but also increases the formation of free oxygen radicals and lipid peroxidation, and this process is called reperfusion injury $(20,30)$. The greatest effects of free oxygen radicals on ischemia-reperfusion injury are on lipid peroxidation. Lipid peroxidation is a very toxic chain reaction. It is important because it is a self-progressing and destructive (30,31). Far worse than, the central and peripheral nervous systems are rich in myelin, a substance rich in lipids. This situation makes the nervous system susceptible to lipid peroxidation.

In this study, sciatic nerve trauma was performed after the administration of cotinine $(0.3 \mathrm{mg} / \mathrm{kg} /$ day $)$ at a dose equivalent to a mild smoker's blood level of cotinine for 21 days. As a result of histopathological examination, it was observed that the most affected fiber type of sciatic nerve was myelinated fibers. The mitochondrial increase in Schwann cells observed after trauma. This increase was evaluated as the response of the cells to oxidative stress. Myelin sheath degeneration concluded that as a result of the oxidative stress on these cells. It was observed that the administration of cotinine increased the degeneration caused by the trauma.

In our study, the histopathological degenerative changes caused by cotinine has been shown, in the rat peripheral nerve experimental trauma model. While small myelinated nerve fibers were observed in normal structure, degenerative changes were observed in large fibers. The number of Wallerian degenerations in the trauma group was significantly lower than in both the drug-control and drug groups. Also, the difference between the drug-control and drug group was also significant. It showed that cotinine administration increased the degeneration caused by trauma, and it was also found to cause fibrosis.

\section{CONCLUSION}

According to these results, regular daily intake of cotinine increases secondary damage related to peripheral nerve injury. Nonetheless it might induce or reduce degenerative process particularly which necessitates dose dependent further investigations. Despite the absence of concrete correlation of histological recovery and neurological findings, the present study demonstrated that cotinine might have additive effects on neurodegeneration and potentially neurodestructive which might be a critical guide to future studies in this field.

Ethics Committee Approval: The study was approved by the Ethics Committee of Ankara Training and Research Hospital (Decision no: 0291/2155).

Conflict of Interest: None declared by the authors.

Financial Disclosure: None declared by the authors.

Acknowledgements: None declared by the authors.

Author Contributions: Idea/Concept: RA, AD; Design: RA, AD; Data Collection/Processing: RA, AD, GT; Analysis/Interpretation: RA, AD, GT; Literature Review: RA, AD, US; Drafting/Writing: RA, AD, GT, US, EÇ; Critical Review: AD.

\section{REFERENCES}

1. Warren CW, Jones NR, Eriksen MP, Asma S. Patterns of global tobacco use in young people and implications for future chronic disease burden in adults. Lancet. 2006;367(9512):749-53.

2. Benner CL, Bayona JM, Caka FM, Tang H, Lewis L, Crawford $\mathrm{J}$, et al. Chemical composition of environmental tobacco smoke and two particulatephase compounds. Environ Sci Technol. 1986;23(6):688-99.

3. Kawachi I, Colditz GA. Invited commentary: confounding, measurement error, and publication bias in studies of passive smoking. Am J Epidemiol. 1996;144(10):909-15.

4. Hegaard HK, Kjaergaard H, Møller LF, Wachmann H, Ottesen B. Determination of a saliva cotinine cut-off to distinguish pregnant smokers from pregnant nonsmokers. Acta Obstet Gynecol Scand. 2007;86(4):401-6.

5. DeLorenze GN, Kharrazi M, Kaufman FL, Eskenazi B, Bernert JT. Exposure to environmental tobacco smoke in pregnant women: the association between self-report and serum cotinine. Environ Res. 2002;90(1):21-32.

6. Rodriguez-Fontan F, Reeves B, Tuaño K, Colakoglu S, D' Agostino L, Banegas R. Tobacco use and neurogenesis: A theoretical review of pathophysiological mechanism affecting the outcome of peripheral nerve regeneration. $\mathrm{J}$ Orthop. 2020;22:59-63.

7. Benowitz NL, Jacob P 3rd, Fong I, Gupta S. Nicotine metabolic profile in man: comparison of cigarette 
smoking and transdermal nicotine. J Pharmacol Exp Ther. 1994;268(1):296-303.

8. Benowitz NL, Jacob P 3rd. Metabolism of nicotine to cotinine studied by a dual stable isotope method. Clin Pharmacol Ther. 1994;56(5):483-93.

9. Simske NM, Krebs JC, Heimke IM, Scarcella NR, Vallier HA. Nerve injury with acetabulum fractures: Incidence and factors affecting recovery. J Orthop Trauma. 2019;33(12):628-34.

10. Ding ZM, Gao Y, Sentir AM, Tan X. Selfadministration of cotinine in Wistar rats: Comparisons to nicotine. J Pharmacol Exp Ther. 2021;376(3):338-47.

11. Lewis DF, Dickins M, Lake BG, Eddershaw PJ, Tarbit MH, Goldfarb PS. Molecular modelling of the human cytochrome $\mathrm{P} 450$ isoform CYP2A6 and investigations of CYP2A substrate selectivity. Toxicology. 1999;133(1):1-33.

12. Visoni S, Meireles N, Monteiro L, Rossini A, Pinto LF. Different modes of inhibition of mouse Cyp2a5 and rat CYP2A3 by the food-derived 8-methoxypsoralen. Food Chem Toxicol. 2008;46(3):1190-5.

13. Benowitz NL. Cotinine as a biomarker of environmental tobacco smoke exposure. Epidemiol Rev. 1996;18(2):188-204.

14. Caldwell WS, Greene JM, Byrd GD, Chang KM, Uhrig MS, deBethizy JD, et al. Characterization of the glucuronide conjugate of cotinine: A previously unidentified major metabolite of nicotine in smokers' urine. Chem Res Toxicol. 1992;5(2):280-5.

15. Hammond SK, Leaderer BP. A diffusion monitor to measure exposure to passsive smoking. Environ Sci Technol. 1987;21(5):494-7.

16. Nakajima M, Fukami T, Yamanaka H, Higashi E, Sakai H, Yoshida R, et al. Comprehensive evaluation of variability in nicotine metabolism and CYP2A6 polymorphic alleles in four ethnic populations. Clin Pharmacol Ther. 2006;80(3):282-97.

17. Hukkanen J, Jacob P 3rd, Benowitz NL. Effect of grapefruit juice on cytochrome P450 2A6 and nicotine renal clearance. Clinical Pharmacol Ther. 2006;80(5):522-30.

18. de Leon J, Diaz FJ, Rogers T, Browne D, Dinsmore L, Ghosheh $\mathrm{OH}$, et al. Total cotinine in plasma: a stable biomarker for exposure to tobacco smoke. J Clin Psychopharmacol. 2002;22(5):496-501.

19. Li Y, Bickel KD, Im MJ, Hu L, Dellon AL, Vander Kolk CA, et al. Effects of deferoxamine on ischemia/reperfusion injury after peripheral nerve compression. Ann Plast Surg. 1996;36(4):365-9.
20. Macchi MM, Bruce JN. Human pineal physiology and functional significance of melatonin. Front Neuroendocrinol. 2004;25(3-4):177-95.

21. Zhang YL, Zhang PB, Qiu SD, Liu Y, Tian YF, Wang $Y$. Effects of ketamine-midazolam anesthesia on the expression of NMDA and AMPA receptor subunit in the peri-infarction of rat brain. Chin Med J (Engl). 2006;119(18):1555-62.

22. Túnez I, Montilla P, Muñoz MC, Drucker-Colín R. Effect of nicotine on 3 nitropropionic acid-induced oxidative stress in synaptosomes. Eur J Pharmacol. 2004;504(3):169-75.

23. Paquette ST, Dawes RP, Sundar IK, Rahman I, Brown EB, White PM. Chronic cigarette smoke exposure drives spiral ganglion neuron loss in mice. Sci Rep. 2018;8(1):5746.

24. Camp CL, Ryan CB, Degen RM, Dines JS, Altchek $\mathrm{DW}$, Werner BC. Risk factors for revision surgery following isolated ulnar nerve release at the cubital tunnel: A study of 25,977 cases. J Shoulder Elbow Surg. 2017;26(4):710-5.

25. Santiago HA, Zamarioli A, Sousa Neto MD, Volpon JB. Exposure to secondhand smoke impairs fracture healing in rats. Clin Orthop Relat Res. 2017;475(3):894-902.

26. Andersen AM, Lei MK, Beach SRH, Philibert RA. Inflammatory biomarker relationships with helper $\mathrm{T}$ cell GPR15 expression and cannabis and tobacco smoking. J Psychosom Res. 2021;141:110326.

27. Chen LE, Seaber AV, Glisson RR, Davies H, Murrell GA, Anthony DC, et al. The functional recovery of peripheral nerves following defined acute crush injuries. J Orthop Res. 1992;10(5):657-64.

28. Kasahara K, Nakagawa T, Kubota T. Neuronal loss and expression of neurotrophic factors in a model of rat chronic compressive spinal cord injury. Spine (Phila Pa 1976). 2006;31(18):2059-66.

29. Boiangiu RS, Mihasan M, Gorgan DL, Stache BA, Hritcu L. Anxiolytic, promnesic, antiacetylcholinesterase and antioxidant effects of Cotinine and 6-hydroxy-L-nicotine in scopolamineinduced zebrafish (Danio rerio) model of alzheimer's disease. Antioxidants (Basel). 2021;10(2):212.

30. Sayan H, Ozacmak VH, Özen OA, Coskun O, Arslan $\mathrm{SO}$, Sezen SC, et al. Beneficial effects of melatonin on reperfusion injury in rat sciatic nerve. J Pineal Res. 2004;37(3):143-8.

31. Cheeseman KH, Slater TF. An introduction to free radical biochemistry. Br Med Bull. 1993;49(3):481-43. 